\title{
DIE INDIKATIEF EN DIE IMPERATIEF IN DIE PREDIKING
}

\section{Inleiding}

Ons lees in die Bybel naas die beloftes van God ook van sy gebooie. Daar is ' $n$ hele aantal wette en voorskrifte in die Woord van God. In die O.T. word die hele wet van God opgesom met as hoogtepunt die bekende Tien Gebooie. By die profete hoor ons herhaaldelik van voorskrifte wat die volk Israel wys hoe God en die naaste gedien moet word. Aan die begin van die N.T. staan daar al dadelik die indrukwekkende Bergpredikassie van Jesus waarin die gebooie van God geproklameer word. 'n Groot gedeelte van die briewe in die N.T. bestaan uit apostoliese vermaninge. Dit is dus 'n vraag hoe ons die gebooie van die Bybel moet verkondig.

Daar word nogal klagtes gehoor in verband met die gangbare prediking oor die gebooie van God. Soms word die gebooie van die Bybel as geïsoleerde wette aan die gemeente voorgehou sodat dit soms meer na wetsartikels uit 'n burgerlike wetboek as na Evangelieverkondiging uit die Woord van God klink. Die prediking ontaard dan in wat ons kan noem 'n soort van ,sambok-prediking'. Die gemeente word gestriem met die wette van God. Die prediker gésel sy hoorders met Gods gebooie.

Wanneer ons die gebooie van God verkeerd verkondig, dreig die gevaar dat ons prediking ontaard in 'n moralistiese sedeles of in ' $n$ aktivistiese program van lewens- en wêreldverbetering. Mense met 'n sterk ontwikkelde wilslewe gryp die gebooie gretig aan en verwag deur gehoorsame wetsvervulling die saligheid. Ander van wie die gevoelslewe weer sterker ontwikkel is, word moedeloos onder die jy-moet- of moenie-prediking.

\section{Wettisisme in die prediking}

In Duitsland het 'n besondere boeiende homiletiek verskyn van die hand van R. Bohren onder die titel: Predigtlehre. In hierdie insig. gewende boek analiseer Bohren die nuwere prediking wat veral deur die teologie van die rewolusie en die sg. politieke teologie beîinvloed is. Hy kom dan tot die konklusie dat die prediking in baie gevalle gekenmerk word deur 'n wettisistiese karakter.'

Wettisisme in die prediking hang nou saam met die nuwe siening op die Koninkryk van God. Die Ryk van God moet op aarde gerealiseer word. Die mens word by hierdie realisering ingeskakel. Hy koöpereer met God. Daar is 'n duidelike sunergistiese trek in die nuwere teologie. ${ }^{2}$ Heil en heiliging word met mekaar verwar. Die reformatoriese teologie sê dat die Kerk die boodskap van heil moet verkondig en dat die mense tot heiliging opgeroep moet word. Maar in die sg. politieke teologie word heiliging self tot heil. Dit wil sê, wat mense doen, word heil vir die medemens. Heil, verlossing word van heiligmaking, van wetsvervulling afhanklik gemaak. In die politieke teologie soos dit veral deur Dorothee Sölle vertolk word, word by name die verlossing van mens en wêreld afhanklik 
gemaak van wat mense doen. Die Evangelie word tot 'n nuwe wet. Dit is ten diepste wat prof. W. J. Snyman genoem het 'n ,judaïsering" van die Koninkryk van God.

\section{Die probleempunt}

Die hele probleem waarvoor die nuwere teologie ons plaas, trek saam in die verhouding van die indikatief tot die imperatief. Die krisis in die hedendaagse prediking bring ons by die vraag hoe ons die gebooie van die Bybel moet verkondig. Hoe moet ons in die Bybel en met name in die N.T., die verhouding sien tussen die indikatief en die imperatief?

Graag wil ek probeer om hierdie uiters belangrike verhouding vir u grammatikaal, struktuuranalities en ook openbaringshistories te skilder.

\section{Die konteks van die gebooie}

Dit moet vir ons baie duidelik wees dat nêrens in die Bybel die gebooie van God as geïsoleerde wette verkondig word nie. 'n Imperatief staan in die Bybel nooit op homself nie. Hy staan altyd in ' $n$ bepaalde kader, in ' $n$ bepaalde konteks. Die imperatiewe in die Bybel is altyd gekoppel aan 'n indikatief. Wanneer ons die gebooie van God van hulle konteks losmaak, wanneer ons in die prediking die imperatiewe losweek van die indikatief, dan gaan hulle op 'n verkeerde wyse in die verkondiging funksioneer.

\section{Sedeprediking}

Aan die een kant is daar die gevaar dat die prediking as verkondiging van losstaande voorskrifte ontaard in sedeprediking. Dit bring ons terug by die teologie van A. B. Ritschl wat die prediking van die Koninkryk van God in wese eties van karakter wou hê. Godsdiens is ten diepste verbetering van die sedelike lewe van die mens. Wanneer die lewe van die mense tot 'n mate eties gepolitoer word, is hulle burgers van die Koninkryk van God.

\section{Herleefde Judaïsering}

Aan die ander kant kan die gebooie van die Bybel in die prediking ook op so 'n wyse uit hulle konteks losgemaak word dat die gehoorsaam aan die wet van God 'n voorwaarde word om in die Koninkryk van God te kan ingaan. Die imperatief gaan dan aan die indikatief vooraf en is ons weer terug by die Joodse verlossingsteologie. Ons vind hierdie benadering van die gebooie van die Bybel by die bekende Nieutestamentikus Joh. Weiss. Ook R. Bultmann beklemtoon die gebooie van God as voorwaarde om deel te ontvang aan die heil van die basileia. Wel handhaaf Bultmann die eenheid van die eskatologiese en die etiese verkondiging, sodat by hom imperatief en indikatief in feite saamval. ${ }^{3}$ 
Kader van die Verbond

Die konteks waarin die Bybel die gebooie plaas, is die Verbond of die Koninkryk. Hierdie twee belangrike Bybelse begrippe is ten diepste identies. Daar is soos J. Behm dit gestel het, 'n korrelasie tussen basileia en diathèkè. Hy noem die nuwe verbond „ein Korrelatbegriff zur basileia".'

Die verbond of die Koninkryk is die groot indikatief wat God daar gestel het. Die verskillende imperatiewe van die Bybel moet altyd in verband met die magtige heilsindikatief van die Verbond of die Koninkryk gepredik word. Verbondsprediking of Koninkryksprediking is daarom die beste middel om 'n verkeerde, eensydige verkondiging van die gebooie van die Bybel vry te spring. Ons moet egter in ons Verbonds- of Koninkryksprediking die lyne van die indikatief na die imperatief en omgekeerd op die regte wyse trek. Die indikatief is op ' $n$ bepaalde manier in die Bybel aan die imperatief verbind.

\section{Die dekaloog}

Ons sal eers in die O.T. nagaan hoe die verhouding van die imperatief tot die indikatief daar gereël is. Die mees sprekende voorbeeld is Ex. 20 waar die Dekaloog, die Tien Gebooie of Tien Woorde vermeld word.

Op 'n geheel besondere wyse in die Tien Gebooie in Ex. 20 verbind aan die eerste vers waar die Here Homself bekend stel as die God van bevryding. Dit is nie moontlik om hier 'n uitgebreide analise van die begrip exodus te gee nie. Daar moet net onthou word dat in die woord exodus die harde kern van versoening opgesluit lê. Verlossing het hier sy diepste betekenis as verlossing van die sonde. Die Here wil sy volk by die verlossing wat Hy verwerf het, ook bewaar. Daarom gee $\mathrm{Hy}$ die Wet vir sy volk.

Die Wet is dus nie gegee om daardeur verlossing te kan verwerf nie. Die Wet is alleen gegee om by die verworwe verlossing te bly. Dit is die rede waarom die Heidelbergse Kategismus die Wet in sy Ou-Testamentiese vorm in die derde deel, die deel van die dankbaarheid gee. Vooraf kry ons by die Tien Gebooie die indikatief van Gods verlossing en daarna volg die tienvoudige imperatief van die gebooie. Ons sien hier dus dat die imperatief in die indikatief gefundeer is.

In die teologie is die waarde van die imperatiewe van die Tien Gebooie dikwels onderskat. In die vorige eeu wou H. F. Kohlbrügge en in hierdie eeu wou Karl Barth die karakter van die imperatiewe van die Wet van God wysig. Beide teoloë het dit so gestel dat die imperatiewe van die Wet van God nie as imperatiewe opgevat moet word nie maar as indicativi futuri, d.w.s. nie meer as 'n gebod nie, maar as 'n belofte."

A. van Selms het egter daarop gewys dat hierdie eksegese van die Tien Gebooie taalkundig nie houdbaar is nie. Ons het hier wel terdeë te doen met imperatiewe ook al staan die negatiewe gebooie 
van die Wet van die Here nie in die imperatiefvorm nie. Van Selms toon aan dat dit in die Semitiese tale nie moontlik is om 'n imperatief met behulp van 'n ontkenning tot ' $n$ verbod te maak nie. Vir 'n negatiewe gebod gebruik die Hebreeuse taal ,lô" met indikatief. Die vierde gebod wat in die positiewe vorm opgestel is, staan wel in die imperatief."

Daar is dus geen rede om die Tien Gebooie om te vorm tot Tien Beloftes nie. Andersyds is die Gebooie ook nie bedoel om die mens daardeur 'n instrument te gee waardeur hy homself kan verlos nie. Ons moet die Tien Gebooie altyd bly sien en ook verkondig in die konteks waarin hulle aan ons meegedeel word.

\section{Die prediking van Johannes die Doper en Jesus}

In die prediking van Johannes die Doper en Jesus hoor ons 'n kragtige imperatief: „Bekeer julle!” (Matt. $3: 2 ; 4: 17$ ). Dit is duidelik dat hierdie oproep tot bekering nie 'n imperatief is wat sonder verband as 'n losstaande uitroep verkondig word nie. Sowel Johannes die Doper as ook Jesus motiveer hierdie imperatief: „want die Koninkryk van die hemele het naby gekom".

Die bekering wat deur Johannes die Doper en Jesus gepredik word, is nie ' $n$ middel om die Koninkryk van God naby te bring of te laat kom nie. Die bekering beteken ook nie dat die mens van sy kant aan 'n voorwaarde moet voldoen waarop God van sy kant dan die Koninkryk laat kom en die mens laat ingaan nie. Die voegwoord $\gamma \alpha \rho$ word in die indikatiewe sin gebruik ,to introduce the reason" 7 waarom die imperatief aangewend word. Die imperatief ,bekeer julle" moet ons sien in verband met die indikatief van die koms van die Koninkryk van God. Die imperatief van die bekering rus in die indikatief van die koms van die Koninkryk van God. Calvyn het by Matt. $3: 2$ so mooi opgemerk dat Johannes nie gesê het nie: doen boete en dan sal die Koninkryk van God naby kom nie, maar hy het allereers die genade van God op die voorgrond gestel en daarna vermaan hy die mense om hulle te bekeer. ${ }^{8}$

Die ware bekering waartoe Johannes die Doper en Jesus oproep, is meer as net nalewing van nuwe reëls en wette, anders bly ons maar beweeg op die vlak van moralisme en wettisisme. Deur die ware bekering kom ons in die ryksgebied van Koning Jesus en laat ons ons beheers en lei en regeer deur Hom as ons nuwe Koning. Daarom is bekering meer as net die doen van 'n aantal goeie dade. Dit is 'n nuwe lewe volgens die orde van die Koninkryk van God. Die ware bekering resulteer in geloof in Jesus Christus en in navolging van Hom.

In die bekende prediking van Jesus op die berg vind ons dieselfde volgorde van indikatief en imperatief. Eers verneem ons die geweldige indikatiewe van die saligsprekinge (Matt. $5: 3-11$ ) en daarna proklameer Jesus die gebooie in kragtige imperatiewe (Matt. 5: 13-7:24). Dit is nie hier die plek om aandag te gee aan die inhoud en die radikaliteit van die gebooie van Jesus nie. 
Ons wil net let op die kader waarin die gebooie deur Jesus geproklameer word.

Die struktuur van die Bergpredikansie is: eers die saligsprekinge en daarna die gebooie. $H$. N. Ridderbos noem die vervulling van die wil van God ,de keerzijde" van die verlossing van die Koninkryk. ${ }^{9}$ Daarom behoort die impertief soos die indikatief tot die gawe van die Koninkryk. Gods opgawe is tegelyk 'n gawe.

Die imperatief tree self ook op in die vorm van heilsverkondiging. ${ }^{10}$ Ons kan nie sê dat die gebooie van God eintlik beloftes is nie. Dan verswak ons die gebodskarakter van die wette en bepalinge van God. Ons kan egter wel sê dat die gebooie van God ook beloftes is.

In die gelykenis van die onbarmhartige skuldeiser (Matt. 18 : 23-35) toon Jesus dit self aan. Op grond van die weldaad van goddelike vergewing word die mens opgeroep om teenoor sy naaste vergewensgesind te wees. Vergewing in die vertikale vlak maak dit vir die mens moontlik om ook op die horisontale vlak vergewing aan sy naaste te skenk. Hierdie bereidheid om te vergewe word deur Jesus voorgestel as 'n vrug van Gods genadige vergewing. Andersyds is die bereidheid om die naaste te vergewe ook 'n toetssteen om te sien of daar werklik geglo word in Gods vergewing. Ons mag dus die kritiese betekenis van die imperatief nie verwaarloos nie. Wie die imperatief nie gehoorsaam volbring nie, kan nie deel hê aan die heil wat in die indikatief voorgestel word nie. By Paulus veral sal ons duidelik die kritiese betekenis van die imperatief sien.

Ons moet egter in die prediking die imperatief nooit van die indikatief skei nie, want beide indikatief en imperatief verkondig vir ons die verlossing wat met die koms van die Koninkryk van God aangebreek het.

\section{Die imperatief in die prediking van Paulus}

In die prediking van Paulus vind ons ook ' $n$ innige samehang tussen die indikatief en die imperatief. In sy bekende rede op die Areópagus hoor ons die imperatief van die bekering. Hier word ons veral getref deur die totalitêre karakter van die imperatief. God verkondig (aldus Paulus) aan al die mense oral dat hulle hul moet bekeer (Hand. $7: 30$ ). Paulus lê in sy prediking te Athene baie sterk die klem op die moet van die bekering.

Die eis tot bekering fundeer Paulus vervolgens in die opstanding en die wederkoms van Christus (vs. 31). Die opgestane Here Jesus is ook die komende Wêreldregter. Hy is Here van almal (Hand. 10 : 36). Die opgestane Here Jesus is Koning, Regter. In die indikatief van die koningskap en regterskap van Christus rus die imperatief om Hom as Koning te erken en as Regter te vrees.

Imperatief rus in indikatief

In die briewe van Paulus vind ons dieselfde karakteristieke struktuur: die imperatief rus in die indikatief. Paulus omskryf die indika- 
tief as die groot openbaringshistoriese gebeurtenis van die sterwe en opstanding van Jesus Christus. Die imperatief is die imperatief van die nuwe gehoorsaamheid. Hierdie imperatief rus in die indikatief van die sterwe en opstanding van Christus (o.a. Rom. $6: 2$ e.v.; Kol. $3: 3$ e.v.; Fil. $2: 12,13$ ).

Telkens vind ons by Paulus dat die imperatief konkluderend rus in die indikatief. Dit kom besonder duidelik aan die lig in die bekende teks Fil. 2 : 12, 13, waar die apostel die inspanning van die gelowige om sy behoud te bewerk fundeer in Gods werk tot verlossing van die mens: ,werk julle eie heil uit met vrees en bewing, want dit is God wat in julle werk om te wil as om te werk na sy welbehae". Die voegwoord $\gamma \alpha \rho$ gee die grond aan vir die opwekking om ywerig te werk. Dit beteken hier hoegenaamd nie dat die indikatief wys op wat God doen en die imperatief op wat die mens doen nie. Dit sou die mens verlei tot sunergisme of werkheiligheid. Indikatief en imperatief is hier veeleer die twee kante van dieselfde saak.

Dit is onmoontlik om die verhouding tussen Gods verlossingswerk en die verantwoordelikheid van die mens vir die verstand aanneemlik te maak. Dit kan alleen in die geloof aanvaar word. Wel wys Paulus ons hier op die innige samehang tussen indikatief en imperatief. So skrywe $H$. N. Ridderbos oor hierdie verhouding: "Indicatief en imperatief zijn beide voorwerp van het geloof, enerzijds in zijn receptiviteit, anderzijds in zijn activiteit. Daarom is het verband tussen beide zo nauw en onlosmakelijk. Zij representeren twee ,zijden" van dezelfde zaak, die niet afgescheiden van elkaar kunnen bestaan". ${ }^{11}$ Hierdie teks toon dat Paulus die imperatief altyd konkluderend laat volg op die indikatief. Hierdie orde kan nie omgekeer word nie.

\section{Imperatief as vrug van heil en toetsteen van geloof}

Dan vind ons by Paulus ook dat die imperatief 'n dubbele funksie het. Aan die een kant wil die imperatief tot openbaring bring wat in die indikatief as heilswerklikheid aangedui is. Die imperatief is duidelik ' $n$ vrug van die indikatief in die lewe van die gelowige. So moet ons die imperatief dan ook predik.

Aan die ander kant het die imperatief egter ook 'n kritiese funksie. Die imperatief is ook bedoel as 'n toetssteen. Waar aanwesig is wat in die heilsindikatief verkondig word, daar sal en moet ook tot openbaring kom wat in die imperatief geëis word. Kenmerkend vir hierdie kritiese funksie van die imperatief is die manier waarop Paulus die imperatief in sy briewe gebruik nl. as 'n nasin (apodosis) na 'n voorwaardelike voorsin (protasis). 'n Voorbeeld hiervan vind ons in Kol. $3: 1$ waar die apostel skrywe: ,As julle dan saam met Christus opgewek is, soek die dinge daarbo waar Christus is en aan die regterhand van God sit". Die partikel $\varepsilon$, die ,indien" of die ,as" in die voorsin, is hier nie hipoteties bedoel nie. Dit is hier eerder ' $n$ veronderstelling waarvan die imperatief as 'n aangenome feit uitgaan. Ons sou hierdie teks dan ook beter kon vertaal met 
„aangesien" of „omdat julle immers saam met Christus opgewek is".12 Ons kry dieselfde grammatikale konstruksie in Matt. 4:3 waar die Satan Jesus versoek met die woorde: „As U die Seun van God is, sê dat hierdie klippe brode word".

Wanneer dit wat in die imperatief geëis word nie sou plaasvind nie, dan is dit wat in die voorsin gestel word nie meer aanneemlik nie. So moet ons die imperatiewe ook aan die gemeente verkondig, prediking van die imperatief as 'n toetssteen waaraan die hoorders hulle geloof kan toets.

\section{Die indikatief moet aanvuur}

In die brief aan die Romeine vind ons 'n duidelike voorbeeld van die wyse waarop Paulus die imperatief met die indikatief verbind. Dit bring ons by die manier waarop die Pauliniese paraenese in sy briewe fungeer.

In die hoofstukke 1 tot 11 van die brief aan die Romeine het die apostel geskrywe oor die beslissende vrae van die Christelike geloof. Ons kan maar sê dat dit in hierdie hoofstukke gaan oor die Christelike leer. Die groot heilsindikatief het Paulus in die hoofstukke 5 en 6 ontvou. Hy het gewys op die betekenis van die offer van Christus, nl. Christus vir ons en ons met Christus. Dan kry ons in hoofstuk 12 die waterskeiding tussen leer en lewe, tussen dogmatiek en etiek. Paulus gaan aan die begin van hierdie hoofstuk oor van die indikatief op die imperatief. Hy doen dit in hoofstuk $12: 1$ met die oorgangspartikel ovv. Alle imperatiewe wat dan in die hoofstukke 12 tot 16 volg, vat hy saam met die werkwoord ,ek

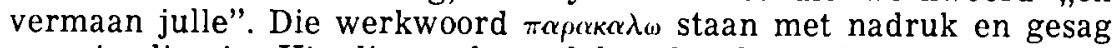
voor in die sin. Hierdie werkvoord kan beteken: versoek, vermaan, vertroos. Maar die grondbetekenis is: „herbeiführen", ${ }^{3 .}$,naderby roep".

Dit lyk vir my dat ons die werkwoord hier in sy grondbetekenis moet gebruik. Paulus skrywe oor die ontferminge van God. Letterlik sou ons daarom hierdie teks soos volg kon vertaal: „Ek roep julle tot by die ontferminge van God". Al die imperatiewe wat volg is bedoel as oproepe dat die lesers by Gods ontferming in Christus Jesus bly.

Dit bring ons ook by die heilskarakter van die imperatiewe. Paulus sê nie vir die gemeente van Rome ,ek gebied julle" nie. So doen die owerheid. Hy gebied en beveel deur sy wette en verordeninge. Ook sê die apostel nie „ek dwing julle” nie. Dit doen die polisiemag, die sterk arm van die owerheid. Ook sê Paulus nie vir sy lesers ,ek adviseer julle" nie. So maak 'n verkoopsman. Nee, Paulus skrywe aan sy lesers „Ek roep julle tot by die offer van Christus, sodat daardie offer julle sal inspireer tot offerbereidheid". Die indikatief van die heilswerk van Christus sal die gelowige aanvuur om die imperatief van die heiligmaking te gehoorsaam.

Dit bewys dat ons nooit die imperatiewe van die Evangelie as geïsoleerde gebooie mag verkondig nie.

Saamvattend kan ons dus sê dat ons die imperatief altyd moet 
predik in noue samehang met die heilsindikatief. Die indikatief is die voedingsbodem vir die imperatief. Soos die indikatief appelleer op die geloof in sy reseptiewe hoedanigheid, so appelleer die imperatief op die geloof in sy aktiewe hoedanigheid. In die betrokkenheid op die geloof van sowel die indikatief as die imperatief is dus die eenheid van indikatief en imperatief veranker. Wat die Bybel so saamgevoeg het, mag ons nie in die prediking van mekaar skei nie. Die imperatiewe van die Evangelie moet ons aan die gemeente verkondig sodat die geloof in die heilsindikatief geaktiveer word.

In die tweede plek moet die imperatiewe aan die gemeente verkondig word sodat die gemeente daardeur gebring kan word tot selfondersoek en vra: is in my lewe aanwesig wat in die indikatief gestel en in die imperatief geëis word? Lewe ek sodanig uit die heilsindikatief dat die heilsimperatief in my lewe werksaam geword het?

Ten derde word die innige maar tegelyk onomkeerbare samehang tussen die indikatief en die imperatief by Paulus duidelik gestel in die omskrywing van die geloof. In Rom. 1: 5 skrywe Paulus dat hy genade en die apostelskap ontvang het „om geloofsgehoorsaamheid te verkry onder al die heidene". Letterlik spreek die apostel hier van die gehoorsaamheid van die geloof. Ons moet $\pi \iota \sigma \tau \varepsilon \omega s$ hier opvat as 'n genitisus subjectivus. Dit gaan hier om gehoorsaamheid waarvan geloof die subjek, die wortel, die bron is, d.w.s. gehoorsaamheid wat uit geloof voortspruit. ${ }^{14}$ Geloof kan ook omskryf word as gehoorsaamheid. Calvyn sê by Rom. 1 : 5: „Hic quoquo observanda est fidei natura: quae nomine oboedientiae ideo insignitur", dit is die natuur van die geloof dat dit as gehoorsaamheid aangedui word. ${ }^{15}$ Joh. $3: 36$ stel geloof teenoor ongehoorsaamheid.

Ten vierde word uit die spanning van indikatief en imperatief soos Paulus dit vir ons aandui, duidelik dat die Koninkryk van God gekom het en dat dit nog moet kom. Ons lewe tussen die koms van die Koninkryk van God as saaityd en die koms van die Koninkryk van God as oestyd. Daarom kan die indikatief die heilswerklikheid van die Koninkryk van God stel, maar daarom moet ook telkens deur middel van imperatiewe die vermaninge gehoor word om te stry.

\section{Die imperatief in die Johanneiese geskrifte}

In die Evangelie volgens en die Briewe van Johannes tref ons dieselfde samehang tussen die indikatief en die imperatief aan. Die imperatiewe is by Johannes nie minder kragtig dan by Paulus nie. Ook vind ons by Johannes dieselfde karakteristieke struktuur: die imperatief rus in die indikatief. Nogtans is daar 'n aksentverskil by Johannes t.o.v. Paulus. Die verskil tussen Paulus en Johannes lê in die omskrywing van die indikatief. Paulus omskryf die indikatief as die groot openbaringshistoriese gebeurtenis van die sterwe en opstanding van Jesus Christus. By Johannes word die indikatief waarin die verskillende imperatiewe rus nie openbaringshistories nie maar veel meer heilsordelik beskryf. Weliswaar vind ons by Paulus wel imperatiewe wat op ' $n$ heilsordelike indikatief gefundeer is soos byvoor- 
beeld in Gal. 5 : 16; Ef. 4 : 30, maar dit is nie die hooflyn van Paulus se denke nie.

In die geskrifte van Johannes is die imperatiewe gebind aan die indikatief van die inwoning van Christus deur sy Gees in die hart. In Joh. 15 : 4 lees ons die sterk imperatief: „Bly in My”. Hierdie imperatief rus in die indikatief wat direk daarop volg, t.w. ,soos Ek in julle". Ons moet by hierdie indikatief, aldus F. W. Grosheide, dink aan die inwoning van die Heilige Gees in die hart van die gelowige. ${ }^{14}$ Deur sy Heilige Gees bly Jesus in ons en op hierdie indikatief rus die imperatief om ook in Hom te bly. „Was gefordert ist, ist schon geschenkt" merk R. Bultmann by hierdie teks op. ${ }^{17}$

In sy eerste algemene brief bind Johannes die gehoorsaamheid aan die imperatiewe van God aan die indikatief van die wedergeboorte. Johannes beskryf die wedergeboorte as 'n geboorte uit God telkens in die perfectum om te wys op ,het afgelopen proces en het blijvende resultaat, en dus: een uit God verwekte, geborene" sê S. Greijdanus. ${ }^{1 *}$ Aan hierdie indikatief van die wedergeboorte verbind Johannes die verskillende imperatiewe soos die doen van geregtigheid $(2: 29)$, die liefde tot die naaste $(5: 1)$, die oorwinning van die wêreld $(5: 4)$ en die opdrag om jouself van die afgode te bewaar $(5: 20,21)$. Die liefde vir die gebooie van God is die gevolg van die inwoning van Jesus in die hart van die gelowige deur die Heilige Gees.

Sowel by Paulus as by Johannes vind ons die gedagtes van representasie en inkorporasie. By Paulus val die nadruk egter op die representasie en hy verbind sy imperatiewe aan hierdie groot gedagte van ons in Christus, terwyl Johannes meer nadruk laat val op die inkorporasie sodat hy sy imperatiewe verbind aan die heer. like feit van die lewensvernuwing deur die Heilige Gees, Christus in ons.

Ons mag in ons prediking geen van twee gesigspunte verwaarloos nie. Die representasie hou verband met die sterwe en opstanding van Christus waarin die gelowige begrepe is, terwyl die inkorporasie verband hou met die uitstorting van die Heilige Gees op Pinkster en die inwoning van Jesus deur sy Gees deur die geloof. Representasie en inkorporasie staan tot mekaar in 'n verhouding van wortel tot vrug.

Ons moet dus die imperatiewe van die Bybel in noue samehang met die sterwe en opstanding van Jesus Christus preek. Ons moet dit egter ook in verband met die uitstorting van die Heilige Gees en die werk wat die Heilige Gees in die hart van die mens doen.

Dit bring ons by die verhouding van die Heilige Gees tot die wet van God.

\section{Die Heilige Gees en die wet van God}

Wanneer die gehoorsaamheid aan die imperatief van die Evangelie vrug is van die verkondiging van die heilsindikatief, is dit dan nog wel nodig om die wet van God te verkondig en om in die prediking aan die paraenese aandag te gee? Jesus het immers in sy gelykenis 
van die saad gesê dat die aarde vanself (in Grieks $\alpha v \tau o \mu \alpha \tau \tau \eta$, outomaties) vrug voortbring (Mark. $4: 28$ ). Moet ons in die prediking nie meer daarop vertrou nie en die verkondiging van die gebooie dan maar vergeet nie?

Luther was al van oordeel dat ons aan die, vanself' aandag moet gee. Hy het met nadruk gestel dat die geloof uit homself, deur 'n innerlike drang en dryfkrag goeie werke sal voortbring. Calvyn was egter nie so optimisties oor die mens nie. Hy het van sy kant met klem gestel dat in die prediking die aansporing en onderrigting van die wet noodsaaklik is om die gelowige te bring tot gehoorsaamheid aan die wet van God. ${ }^{19}$

Ons aanvaar saam met Calvyn dat die gebooie van God deur ons verkondig moet word. Hulle moet egter nie gepredik word om daardeur verlossing te kan verwerf nie, maar wel om by die verworwe verlossing te bly. Die Heilige Gees rig die lewe van die gelowige op die wet van God - nie om daarmee jets verdiensteliks te presteer nie, maar om God te eer."

Prof. L. J. Botha het in sy Homiletiek aangetoon dat uit reaksie teen die semi-Pelagianisme van die $16 \mathrm{e}$ eeu, uit reaksie teen die Remonstrantisme van die $17 \mathrm{e}$ eeu, uit reaksie teen die moralisme in die $18 \mathrm{e}$ eeu en ook uit reaksie teen allerlei sunergistiese rigtings wat werkheiligheid in die $19 \mathrm{e}$ en $20 \mathrm{e}$ eeu verkondig het, was die prediking van protreptiese (aansporende stowwe) by baie Gereformeerdes nie geliefd nie. „Ons mag egter”, so skrywe prof. Botha, „nie hierdie stof in die prediking vermy nie. Ons moet die volle Woord van God verkondig. Maar dit dan ook in die regte verband. Onthou moet word dat die geloof en die werke onlosmaaklik aan mekaar verbonde is. Die prediking mag nie geloof sonder werke verkondig of werke sonder geloof nie. Dan wyk hy af van die regte leer van die Skrif".21

Die onlosmaaklike samehang tussen geloof en werke waarop Botha hier wys, is die weerspieëling in die lewe van die gelowige van die onlosmaaklike verband wat daar tussen die indikatief en die imperatief van die Evangelie bestaan.

Prof. Hugo du Plessis het hom ook besig gehou met hierdie verhouding tussen indikatief en imperatief. Hy het dit so gestel: „Daar is dus enersyds die indikatief van God se werk in die gemeente en andersyds die imperatief van die gemeente om self tot werksaamheid oor te gaan. Sonder hierdie indikatief is die imperatief van sy drang en krag ontroof, maar selfs in die imperatief gaan Christus self saam met sy gemeente en handel Hy deur sy gemeente".22

Ons kan hieruit leer dat die imperatief soos dit in die Evangelie verkondig nie alleen 'n opgawe is nie, maar tegelyk ook 'n gawe.

Die imperatief van die Bybel het stellig ook die bedoeling om die mense tot verootmoediging en skuldbesef te bring. Dit kan ons die negatiewe betekenis van die imperatiewe noem. Dit ontdek die gemeente aan haar tekortkomings, sondes en gebreke. Ons kan hieruit leer dat ons God nie met so'n ywer dien as wat ons verskuldig is nie.

Mens kan egter ook 'n positiewe betekenis van die imperatiewe 
noem, naamlik dat hulle in die Bybel ook as gawe verkondig word. ${ }^{23}$ Die eerste drie bedes van die Onse Vader leer dit nadruklik. Ons mag van God afsmeek wat Hy van ons vra om te doen. „Daarom staan deze gebeden met Jezus' geboden ook in nauw verband". ${ }^{24}$ Die imperatief, die gebod soos dit in die prediking verkondig moet word, sal daarom die mens moet bring tot gebed. Hierdie gebed is 'n gebed om die Heilige Gees, want die inhoud van Gods gawe is die Gees van Jesus Christus wat uitgestort is en wat woon in die Kerk. Die Heilige Gees alleen stel die mens in stat om die wil van God te gehoorsaam. „Hij schept en onderhoudt de gemeenschap tussen de Vader en zijn kinderen. Hij is ook het beginsel van de heiliging van Gods naam en het reschieden van Gods wil op aarde, Hij ontneemt de gelovigen de zorg voor het dagelijkse brood, geeft hun de zekerheid van de vergeving der zonden en bewaart hen voor de macht van de boze". ${ }^{25}$ Ek dink hier aan die bekende gebed van Augustinus: „Domine, da quod iubes, iube quod vis", Here, gee wat $U$ eis en eis dan van my wat $U$ maar wil.

In die Evangelies word nog maar min eksplisiet oor die gawe van die Gees as heilsbesit van die gelowige gespreek. Tog kan ons nie ontken nie dat die saamgaan van die Koninkryk van God en die Heilige Gees een van die groot veronderstellinge van die Evangelie vorm. ${ }^{26}$ In die briewe van Paulus kom die verband tussen die Heilige Gees en die Koninkryk van God duideliker en meer eksplisiet aan die lig. Paulus wys dikwels daarop dat die Heilige Gees die groot Inaugurator én ook die groot gawe van die eindtyd is, die eindtyd wat met die opstanding van Christus aangebreek het. Dit is met name die Heilige Gees wat die gelowige bind aan die wil en aan die wet van God, nie om deur wetsgehoorsaamheid die saligheid te verwerf nie, maar om daardeur God te dien. ${ }^{27}$

Vryheid van die wet beteken nie vryheid van die inhoud van die wet nie. Wel word die gelowige bevry van die veroordelende krag van die wet. Deur die Gees word die gelowige op 'n nuwe wyse aan die gebooie van God gebind nl. om met liefde en in volharding die wil van God te gehoorsaam.

In die geskrifte van die apostel Johannes word op die inwoning van die Gees en op die gawe van die Gees as heilsbesit van die gelowige gewys in verband met die gehoorsaamheid van die gebooie van God. In die lig hiervan kan ons sê dat die verkondiging van die imperatiewe van die Bybel ten diepste altyd 'n verwysing is en moet wees na die belofte en die werk van die Heilige Gees. Die gebooie van die Bybel moet dan ook in die kader van die koms en die werk van die Heilige Gees verkondig word. Verbondsprediking of Koninkryksprediking sal ons telkens weer daartoe bring om die gebooie van die Bybel sowel openbaringshistories as ook heilsordelik te verkondig in verband met die koms en die werk van die Heilige Gees. Die gebod sal so die gemeente dryf tot gebed en om te bid om die Heilige Gees.

\section{8. 'n Preekskets}

Wat ek hierbo opgemerk het, wil ek met 'n voorbeeld in die vorm 
van 'n preekskets verduidelik. Ons kies vir hierdie doel een van die kort imperatiewe waaraan die briewe van Paulus so ryk is nl. die

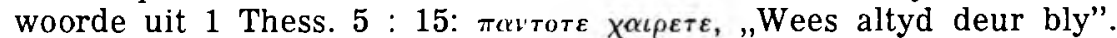
Dit is 'n kragtige imperatief wat Paulus voorhou aan die gemeente te Thessalonika. Die werkwoord staan in die imperatief praesens waardeur reeds die voortdurende beklemtoon word. Dit word nog

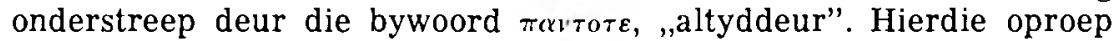
tot voortdurende blydskap steek wel besonder skerp af teen die toestand in die gemeente aldaar. Die lidmate van die gemeente word vervolg. Hulle moet van hulle volksgenote dieselfde dinge ly wat die Christene uit die Jode van hulle volksgenote moes verdra ( 1 Thess. 2 : 14). Teen hierdie agtergrond van lyding en dreiging vermaan Paulus tot voortdurende blydskap.

Alvorens ons die imperatief van die blydskap aan die gemeente verkondig, moet ons eers die indikatief van die blydskap predik. Paulus doen dit self ook in hierdie brief. Ons mag egter ook uit ander briewe van Paulus of ander gedeeltes van die Bybel put om die indikatief van die blydskap goed te kon verkondig.

Die apostel Paulus karakteriseer in sy briewe die begrip blydskap tweevoudig. Hy bring die selfstandige naamwoord „blydskap" of die werkwoord ",bly wees" in verband met Christus én met die Heilige Gees. Daar is dus by Paulus 'n Christologiese én 'n Pneumatologiese benadering van die begrip „blydskap". In Fil. $4: 4$ dui

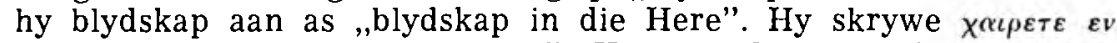
$\kappa v \rho \iota \omega$, ,verbly julle in die Here". Hier word die werkwoord ,bly wees" openbaringshistories benader. Christus is die Kurios. Hy het deur sy opstanding die dood oorwin. Hy het ons lewe verlos van die dood, die dood as oordeel en straf op die sonde. Die blydskap wat Paulus hier bedoel is dus primêr 'n blydskap oor die werk van Christus. Dit is ' $n$ blydskap oor sy oorwinning. Dit is egter ook 'n blydskap wat net in gemeenskap met Christus beoefen kan word. Ons is in Hom begrepe. Kragtens ons begrepenheid in Christus het ons saam met Hom opgestaan.

Die blydskap wat Paulus beoog en waartoe hy die gelowiges te Thessalonika oproep rus dus nie in die omstandighede van die lewe nie, maar dit rus in die volbragte werk van Christus.

Hoe sal ons egter voortdurend bly kan wees? Hoe moet ons dit in die daaglikse praktyk van die lewe beoefen? Dit voel vir ons te hoog, te ver, te onwerklik.

Paulus gee egter nog 'n tweede aanduiding van hierdie blydskap. In 1 Thess. $1: 6$ noem hy die blydskap 'n blydskap van die Heilige

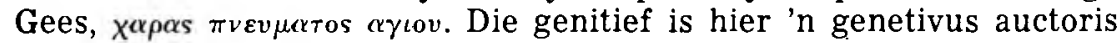
of qualitatis. Die Heilige Gees is die Bewerker van die blydskap. Ons is nie in staat om in die storms van die lewe en die stryd van elke dag die blydskap van Christus vas te hou nie. Die Heilige Gees bewerk egter die blydskap. Daarom is die blydskap 'n gawe van die Heilige Gees. Die imperatief „wees altyddeur bly”, rus dus ook hier in die indikatief. Wat in die Woord van God gevra, geëis, beveel word, word ook belowe. Die Gees bewerk die geloof, ook die geloof in die imperatief. 
Die geloof in sy reseptiwiteit aanvaar die indikatief en die geloof in sy aktiwiteit gehoorsaam die imperatief. Die Gees bind aan Christus die bron van die blydskap. Die Gees leer ons om te glo in die werk van Christus waaruit die blydskap ontspring.

Die gebod om bly te wees, is dus bedoel om diegene wat dit hoor te bring tot die gebed. Dit is dan ook besonder treffend dat Paulus in 1 Thess. 5 op die imperatief ,wees altyddeur bly", 'n nuwe imperatief ,bid sonder ophou" (1 Thess. 5 : 17) laat volg. Voortdurende blydskap kan nie sonder onophoudelike gebed beoefen word nie.

\section{Slotbeskouing}

Op die vraag hoe ons die gebooie van die Bybel moet verkondig, kan ten slotte saamvattend geantwoord word: ons moet die imperatiewe van die Bybel altyd predik in samehang met die magtige indikatief, die heilsindikatief van die Verbond en die Koninkryk van God.

Ons moet die imperatiewe van die Bybel ook in hulle kritiese funksie in ons prediking laat werk as 'n toetssteen waaraan die hoorders hulle geloof moet toets.

Ons moet veral ook die imperatiewe van die Bybel verkondig as 'n gawe van God. Wanneer ons die imperatiewe van die Bybel in hulle openbaringshistoriese en pneumatologiese verbande verkondig, sal dit verhoed dat ons in die rigting van sunergisme of werkheiligheid afgly en dan sal die gemeente opgewek word tot geloof en tot goeie werke as vrug van 'n ware geloof.

Wanneer ons vashou aan die groot gedagte van die Skrif dat die imperatief rus in die indikatief, het ons ' $n$ wapen teen die invloed van die nuwere teologie wat heil en heiliging met mekaar verwar en wat die verlossing van mens en wêreld selfs afhanklik maak van wat mense doen.

Veral in ' $n$ tyd soos hierdie is dit van die uiterste belang dat ons vashou aan die Bybelse verhouding tussen indikatief en imperatief: hulle is onlosmaaklik aan mekaar verbonde en hulle volgorde is onomkeerbaar.

L. Floor.

(Gelewer voor die G.T.V. Suidwes-Afrika en G.T.V. Pretoria).

\section{AANTEKENINGE}

1 R. Bohren: Predigtlehre, 19722, p. 115, 283.

2 W. Schmithals: Jesus und die Weltlichkeit des Reiches Gottes, In: Evangelische Kommentare, 1968, p. 318.

3 R. Bultmann: Theologie des Neuen Testaments, I, 1948, p. 19, 20.

4 J. Behm: Theol. Wörterbuch zum N.T., II, p. 137.

5 Th. Stiasny: Die Theologie Kohlbrügges, s.j., p. 18; K. Barth: Evangelium und Gesetz, s.j., p. 18.

6 A. van Selms: Evangelie en wet, in: Onder eigen vaandel XIII, p. 2, 99.

7 Liddell-Scott's Greek-English Lexicon, p. 138.

8 Calvyn: Comm. in Harm. Evang. C.R., p. 111.

9 H. N. Ridderbos: De komst van het Koninkrijk, 1950, p. 223.

10 H. N. Ridderbos: a.w., p. 225. 
11 H. N. Ridderbos: Paulus, ontwerp van zijn theologie, 1966, p. 282.

12 Vgl. vir die gebruik van a Blasz-Debrunner, Gramm. \$372,7; \$439,2; \$454,2.

13 O. Schmitz: Th.W.B. V, p. 777.

14 H. N. Ridderbos: Aan de Romeinen, 1959, p. 27.

15 Calvyn op Rom. 1 : 5.

16 F. W. Grosheide: Het heilig Evangelie volgens Johannes II, 1950, p. 338.

17 R. Bultmann: Das Evangelium des Johannes, 1952, p. 412.

18 S. Greijdanus: De brieven van de apostelen Petrus, Johannes en de brief van Judas, 1929, p. 469.

19 Vgl. J. Douma en H. van der Vegt: Het gepredikte Woord, IV, s.j., p. 7.

20 W. H. Velema: Verkenningen in Iromeinen, 1962, p. 61.

21 L. J. Botha: Diktaat Homiletiek, Teol. Skool Hammanskraal, s.j., p. 17.

22 H. du Plessis: Die sendingroeping in die verhouding tot die werk van God, in: Die saailand is die wêreld, 1972, p. 28.

23 H. N. Ridderbos: De komst van het Koninkrijk, 1950, p. 221.

24 H. N. Ridderbos: a.w., p. 222.

25 H. N. Ridderbos: a.w., p. 232.

26 H. N. Ridderbos: a.w., p. 233.

27 J. P. Versteeg: Christus en de Geest, 1971, p. 381; vgl. H. N. Ridderbos: Paulus, ontwerp van zijn theologie, 1966, p. 234 e.v. 